\title{
Power Ranges:
}

\section{Identity and Terrain in Minoan Crete}

\author{
Caroline Tully \\ School of Historical and Philosophical Studies, Faculty of Arts, University of Melbourne, \\ Parkville 3010, Australia \\ tullyc@unimelb.edu.au
}

\section{Sam Crooks}

Department of Archaeology and History, School of Humanities and Social Sciences, College of Arts, Social Sciences and Commerce, La Trobe University, Bundoora 3086, Australia

sgcrooks@outlook.com

\begin{abstract}
During the Aegean Bronze Age, the island of Crete was home to Minoan civilisation (3100-1300 $\mathrm{BCE}$ ). The Cretan landscape is characterised by prominent mountain ranges. During the Middle Bronze Age (ca. 2000 BCE) cult sites began to proliferate on mountain peaks in response to climatic changes. Peak sanctuaries were locations of popular religious expression focussed on human, animal and environmental health and fertility. In the Neopalatial Period (1750-1490 BCE) peak sanctuary cults were appropriated by palatial elites and the Minoan cosmological framework, oriented towards mountains, was institutionalised. Analysis of the Minoan landscape, palatial art, architecture and ritual performance demonstrates a close association between elite figures and real and symbolic mountains. The metaphysical terrain of Crete was politicised as mountain symbolism was used to naturalise Neopalatial elite status and identity. The mountain form signified and symbolised power relations functioning as an instrument of elite ideology.
\end{abstract}

Minoan Crete, Mountains, Elites, Ideology 
The island of Crete, located in the Mediterranean, is topographically dominated by mountainous terrain. Inhabited from the Neolithic Era (7000 BCE), Crete was home to the Minoan civilisation which flourished during the Middle Bronze Age (the Protopalatial period 2000-1750 BCE), before earthquakes destroyed the first Minoan palaces between around 1850-1750 BCE. After the palaces were rebuilt, Minoan civilisation reached its zenith during the Late Bronze Age (the Neopalatial period 1750-1490 BCE). An aridity event around 2200/2000 BCE brought substantial change in climate coinciding with the appearance of cult sanctuaries on mountain peaks as herders and their flocks were forced upland for livestock subsistence. The deposits at such sites reflect pastoral and agrarian concerns and relate to health and fertility in livestock and humans. Mountains were instrumental to survival, functioning not only as a source of fresh water (rivers flow down from mountains), but also providing pasture for grazing at a time when the Minoan culture was suffering ecological challenges and substantial social and environmental change.

Close archaeological analysis of Minoan terrain, architecture, iconography and ritual practice demonstrates that the Minoans perceived a tripartite cosmological ontology founded in an animate natural world (Crooks et. al. 2016; Tully 2018b). This worldview was profoundly influenced by and engaged with landscape and the environment, and above all, oriented towards mountains. Minoan reverence towards mountains finds expression in the presence of cult sites upon mountain peaks, as well as in architectural forms and iconographic representation. During the Cretan Neopalatial period, Minoan palatial elites institutionalised this tripartite cosmological framework oriented towards sacred mountains through ritual performance in conjunction with mountain symbolism. Mountains subsequently became instrumental in the naturalisation of elite status and identity as Minoan elites positioned themselves as intermediaries between the populace and the (super)natural landscape, and as the progenitors and arbiters of fertility and subsistence. Adopting the Peircean concept of replication, in which objects, places, and both built and natural forms are viewed as instantiations of social and cosmological ideals, Minoan palaces and cult furniture are interpreted as symbolic landscapes that instantiate the cosmological axis mundi in which Minoan elites occupied a mountainous seat of power within a sacred urban and natural landscape. While the association of elite male figures and symbolism with cult sites upon mountains has previously been demonstrated (Haysom 2018), it will be shown for the first time here that there was a pronounced association between elite females and sacred mountains within urban locations.

\section{Minoan Crete}

The Minoan civilisation was discovered at the beginning of the twentieth century by British archaeologist, Sir Arthur Evans. A guiding influence of archaeological practice during the Victorian era was to discover the origins of European civilisation, the founding literature of which was the Homeric epics, the Iliad and Odyssey (dating to the early Archaic period around 700 BCE). German archaeologist, Heinrich Schliemann, had excavated Troy and Mycenae 
almost three decades earlier and found apparent proof of the reality of the Trojan War and by implication legendary characters such as Achilles, Paris, Helen, Agamemnon and Clytemnestra. So too Evans' excavation of the palatial site of Knossos on Crete seemed to verify the reality of famous figures from Greek myth. Evans projected Homeric, Hesiodic, and Classical myth about Crete retrospectively to the Bronze Age Minoans. He identified the Minoan deities as Rhea and Zeus and peopled the palace of Knossos with the well-known figures of Minos (after whom Minoan culture was named), Pasiphae and the Bull, Theseus, Ariadne, Dionysus and, inspired by the palace's maze-like architecture, the Minotaur in the Labyrinth (Evans 1921; 1928; 1930; 1936). Impressed by the wealth and sophistication of the material culture uncovered in his excavations, Evans proclaimed the Minoans to be the oldest civilisation in Europe (McEnroe 1995; McGillivray 2000; Momigliano 2006; Trigger 2006; Gere 2009; Eller 2012).

Crete is the largest of the Greek islands and is located in the Mediterranean on the ancient sea routes between Europe, Asia, and Africa, a position that contributed to its important role in the network of trade and transmission of culture throughout the ancient world (Tully 2018a). First inhabited in the Neolithic period (ca.7000-3500 BCE), small hamlets and villages remained the dominant settlement pattern until the end of the Early Bronze Age (the Middle Minoan IAIB ca. 2000 BCE). From the Middle Bronze Age onward, a more complex society emerged which culminated in the appearance of the first palaces, termed the Protopalatial period (Middle Minoan IB-IIIB ca.2000-1750 BCE). Destruction of the palaces, probably by a series of earthquakes, and their subsequent rebuilding marked the beginning of the Neopalatial period (Late Minoan IA-B) around 1700 BCE. The Minoan palaces formed the centre of administration, storage, trade, and religion until their destruction by the Mycenaeans in the Final Palatial period (Late Minoan IB-II) around 1490-1430 BCE, with Knossos itself finally destroyed around 1350 BCE (Tomkins 2010; Manning 2010). While the Minoans possessed writing systems, the hieroglyphic and Linear A texts remain undeciphered and while the Linear B texts from Mycenaean Knossos and Pylos provide some insight, we rely primarily on archaeological evidence including architecture, iconography, crafts and the environment in reconstructing Minoan culture.

The island of Crete is 215 kilometres long and 57 kilometres wide at its widest part and features a mountainous limestone spine consisting of fifteen mountain ranges, three of which exceed $2000 \mathrm{~m}$ in height. These extend the length of the island from east to west and dominate it topographically (Rackham and Moody 1996). The ranges of Dikte in the east (2148m), Ida in the centre (Psiloritis $2456 \mathrm{~m}$ ), and Leuka in the west (2452m), divide Crete into a series of coastal lowlands, plains, plateaus, and foothills. Most of the important Minoan archaeological sites are concentrated in the centre and east of the island. The west of the island was less favourably positioned to take advantage of the sea trade routes and did not possess the habitable lowlands and safe harbours evident elsewhere on the island (Crooks 2013).

The natural landscape as a theme within Minoan art has long been the focus of scholarly attention (Crooks in press a). The emergence of landscape archaeology in the 1990s established 
new understandings of the cultural significance of the natural world (Tilley 1994; Ashmore and Knapp 1999). Rather than seeing nature as separate from culture or as a monolithic and essentialised abstraction, nature was reconfigured as a cultural construction whereby humans in dialogue with the natural world formed cultural landscapes (Goodison 2012). Such cultural landscapes are conceived as being not only 'natural' but also inherently political, serving ideologically to normalise the status quo, resolving tensions inherent in status inequality through naturalising them in material terms. Symbolic cultural landscapes include the terrestrial planes of human activity as well as natural phenomena including diurnal and seasonal cycles, and celestial elements such as the sun or the night sky.

Once considered merely an inert backdrop for human activity or as a series of material affordances or constraints, landscape has increasingly come to be understood as a 'stage constructed in the mind' (Ashmore and Knapp 1999: 8) comprising taskscapes of nested activities, palimpsests of memory, association and affect, sites of situated in-dwelling, accumulation, and inscribed attachments over time (Knapp 1999: 230-231; Kosiba 2012: 97; Tilley 2008: 273, Bender 1998: 60; Bender et al. 1997: 174; Ingold 1993: 153, Fowler 2008: 296; Hicks 2016:12; Hoskins 1955, Barrett 2003: 27-30; Casey 2008: 48; Chapman 1997: 37 , 2008: 198, 2012: 89; Heidegger 1971; Thomas 2008: 305; Zedeño 2008: 213).

Phenomenologically, space and time converge in place, a dialectical position which recursively shapes and is shaped by human agents and thus anchors human ontologies in time and place (Casey 1996: 36; Tuan 1977; Crooks in press b). During the Neopalatial period on Crete the mountainous landscape was given physical symbolic form through monumental architecture, cult structures, ritual performance, special garments, and within iconography. Through these forms of instantiation (Peirce 1935: 143; Cohen 2006), knowledge and control over the Cretan landscape was socially restricted and utilised as a means for Neopalatial elites to achieve authority.

\section{Nature and Landscape in Minoan Iconography}

From the beginning of the study of Aegean prehistory the significance of the natural landscape within Minoan culture was evident. Evocative and lively representations of the natural world, characterised by a profusion of animal and plant life, are abundantly illustrated across a range of media including wall-painting, ceramic decoration, and administrative seals and sealings. The foregrounding of the natural world in Minoan art led to a Romantic interpretation of Minoan society as a peaceful, nature-loving, pre-modern utopia dwelling in an idealised past (Groenewegen-Frankfort 1951).

Influenced by the Victorian comparative ethnologists, Sir Arthur Evans proposed that Minoan religion was characterised by ecstatic ritual involving consumption of psychoactive substances, divine possession, frenzied shaking of sacred trees, and hugging of aniconic stones (baetyls) (Evans 1901; Graesser 1972; Avner 1993; Crooks 2012; 2013; Tully and Crooks 
2015). ${ }^{1}$ Evans' model posits a primitivist, animistic ontology upon Minoan cults, in which elements of the natural landscape such as trees, stones, springs, groves, mountains, and caves are considered sacred abodes inhabited by supernatural forces or spirits (Evans 1901; Warren 1988; Herva 2006; Crooks 2013; Tully 2018b).

Archaeological evidence appears to confirm aspects of Evans' model, with the identification of rural sanctuaries situated within the natural landscape away from urban locations. These nature shrines, located within caves, on hills, and on mountain peaks, are characterised by varying degrees of architectural elaboration, the presence of votive offerings, and evidence of ritual activity. Natural features are central to the ritual activities performed at these sites which are variously oriented toward springs, chasms or fissures within rock, pools of water, or rock formations within caves.

\section{Minoan Mountain Sanctuaries}

In the Early Minoan period religion was focussed on ancestor veneration and ritual was enacted in the vicinity of monumental stone tombs (tholoi). Ethnographic anthropologies have shown a common association between death and fertility (Bloch and Parry 1982; Huntington and Metcalf 1979; Kan 1989; Strathern 1996). The Early Minoan tholos tombs, positioned on the plain of the Mesara in central Crete, replicate mountainous forms rising skyward from the expansive lowland plains. ${ }^{2}$ At the end of the Early Minoan period mountain peak and cave cults arose in response to environmental change. An aridity event affecting the east Mediterranean around 2200/2000 BCE dried up lowland pastures, coinciding with the establishment of ritual sites on mountain tops and within caves, places close to the sources of rain and groundwater (Moody 2009: 248-9). The monumental palaces, characterised by huge food storage areas, were also built at this time only to be destroyed by earthquakes between 1850-1750 BCE (Macdonald 2017: 331, 333). The rebuilding and construction of new palaces from around $1750 \mathrm{BCE}$ paralleled the decrease of mountain sanctuary sites, perhaps as a result of the improvement of the summer climate due to the second millennium 'Little Ice Age' (Moody 2009: 246).

Peak sanctuaries are some of the best known and most visible cult places in Aegean prehistory. Their location suggests that mountains held special significance for the inhabitants of Minoan Crete. Archaeological investigation has identified around forty Minoan mountain peak and hill sanctuaries (Peatfield 1994; Nowicki 2007; Davis 2014). ${ }^{3}$ During the Middle Minoan

\footnotetext{
${ }^{1}$ Baetyls are natural and worked stones traditionally thought to be aniconic representations of a deity, similar to Levantine masseboth.

${ }^{2}$ Of the more than 70 tholos tombs known from 45 different sites, the majority are located in and around the Mesara plain. Although only several meters high, the beehive-shaped stone tholos tombs evoke mountains in a manner similar to Egyptian pyramids and Mesopotamian ziggurats, albeit on a smaller scale.

${ }^{3}$ The number of sites identified as peak sanctuaries has fluctuated since their original identification, with very few sites adequately excavated and fewer still published. Platon (1951) provided the first detailed study, counting eleven sites. After extensive field survey, Faure (1969)
} 
period these were distributed throughout eastern and east-central Crete and were locations of popular cults. Peak sanctuary sites are characterised by a combination of topographical and archaeological features which include: location at or near the summit of a mountain, within the range of human exploitation and transhumance of livestock; prominence of the mountain within the local region; an expansive viewshed from the sanctuary site; intervisibility between the settlement, the sanctuary site, and individual peak sanctuaries; proximity to settlements and accessibility, i.e. between 1-3 hours walk to reach the sanctuary (Peatfield 1983; 1990; 1987; 1994; 2009). The appearance of peak sanctuaries coincided with the movement of pastoralists upland in response to environmental change (Rutkowski 1986: 94; Moody 2009: 248). Thus, mountains became essential to survival during the time of ecological and social upheaval.

Middle Minoan peak sanctuaries display a distinct artefactual pattern including terracotta human and animal figurines, and human anatomical body parts. Waterworn pebbles, likely sourced from freshwater rivers, are known from several sites and may have been used to demarcate the ritual area and/or been connected to the ritual supplication for rain (Nowicki 1994). The human figurines are considered votive offerings representing human worshippers rather than deities, as no definitive cult image has ever been identified in Minoan figurative art (Marinatos 1993). The figurines were probably offered in thanks for protection or as memorials of individuals in their act of dedication (Peatfield 1990). The human limbs, which include arms, legs, heads, and genitalia, may have been used to petition for protection, healing of particular body parts, fertility, or as thanks for a cure (Peatfield 1990; Arnott 1996). ${ }^{4}$ The animal figurines are primarily bovine but include goats, sheep, birds, weasels, and beetles. These may have been apotropaic or memorialized, or have substituted an animal sacrifice. The presence of animal bones and greasy ash layers provide evidence of bonfires, feasting, and sacrifice (Peatfield 1983; 2009; Watrous 1996; Jones 1999). The expansive viewsheds of peak sanctuaries may suggest that they were used as beacons, and they may have also been used for astronomical observation (Peatfield 1983; 1987; 2009; Kyriakidis 2005; Blomberg and Henriksson 2016) (fig. 1).

\section{[Figure 1 near here]}

Figure 1. Mount Juktas with the modern city of Heraklion in the foreground (photo by John Handy).

raised the number to over fifty sites, however subsequent reinvestigation has reduced that number, Rutkowski (1986) counting thirty-seven and Peatfield (1990) further reducing their number to a conservative twenty-five sites. The exact figure continues to be debated (Nowicki 1994; Watrous 1995; Davaras 2010). We may add two more recently investigated peak sanctuaries of Minoan character located on the island of Kythera (Sakellarakis 1996; Georgiadis 2012).

${ }^{4}$ Votive limbs are known from only half the peak sanctuary sites (Briault 2007, 125), suggesting the concerns of people visiting these places were not uniform. 
Mount Jouktas near the palace of Knossos is the oldest and most monumentalised peak sanctuary and has produced the largest and most extensive assemblage.

During the Neopalatial period (1750 -1490 BCE) the number of active peak sanctuaries decreases to only eight, possibly as a result of improvement of the climate due to the second millennium 'Little Ice Age', caused by a combination of glacial advances in Europe and other regions, sunspot minima, and the volcanic eruption on Thera (ca. 1628 BCE) (Moody 2009: 246, 249). These remaining sanctuaries, all located near urban centers and palaces, were architecturally elaborated and exhibit high quality offerings, suggesting that they came under the control of palatial elites (Peatfield 1987; 2009; Kyriakidis 2005; Davis 2014; Crooks et al. 2016). Neopalatial peak sanctuaries feature enclosure walls, single or multiple storage rooms built roughly of local stone, and terracing to level out the approach. Cult furniture such as altars, benches and rock tables are also evident, along with the presence of human and animal figurines, votive limbs, hearths, ash, evidence of feasting, metal blades, jewellry, and objects inscribed with the palatial writing script, Linear A (Davis 2014; Haysom 2018). This suggests the appropriation of a popular cultic tradition during this period by palatial elites seeking to legitimise their privileged status and authority through associating themselves with the numinous power connected to mountains (Crooks et al. 2016; Tully and Crooks in press). ${ }^{5}$

The relief on a steatite rhyton from Zakros in east Crete provides a representation of a Neopalatial peak sanctuary (fig. 2). In addition to depicting a peak sanctuary within a mountainous setting, the image portrays a stylised mountain peak flanked by goats, surmounting a tripartite shrine (Shaw 1978). The position of the mountain between the goats underscores its significance as arrangements of central objects flanked by animals or fantastical composite creatures commonly signify the power or status of the central figure (Crowley 1989).

\section{[Insert Figure 2 near here]}

Figure 2. Drawing of the carved relief depicting a peak sanctuary on a stone rhyton from Zakros (Joseph Shaw 1978, fig. 8).

\section{Mountains and Power}

\footnotetext{
${ }^{5}$ The Neopalatial period is characterised by the rebuilding on a more monumental scale of palatial structures destroyed in the preceding Middle Minoan II period. Increased unification across the island is centred on the palace of Knossos and management of agricultural production, surplus storage, trade in commodities, and the expansion of Minoan cultural influence within the Cycladic islands are evident (Driessen et.al. 2002; Rehak and Younger 1998). During this period Minoan palatial control was exerted through a system of villas and religious sites including cave and peak sanctuaries.
} 
As a result of the lack of translated texts from Bronze Age Crete, study of Minoan sacred mountains relies primarily upon iconographic and archaeological evidence. Understanding the significance of mountains in Minoan Crete can be enhanced by considering comparative ethnographic and ethnohistoric evidence from cultures that are geographically and chronologically proximate to, and which were also in contact with, Neopalatial Crete. ${ }^{6}$ Within the wider Mediterranean world, mountains were associated with power, authority, and order. In Canaanite and Israelite religion, mountains were associated with deities such as El, Baal, and Yahweh; deities who were the leaders of their pantheons. El's mountain was a source of water and fertility and the meeting place of heaven and earth. It represented royalty and governance and was the place where the divine council met. In Hittite, Canaanite, and Israelite myths storm deities such as Teshub, Baal, and Yahweh dwelt upon mountains and manifested in displays of thunder and lightning (Clifford 1972). The predominance of bull figurines and monumental 'Horns of Consecration' on Minoan peak sanctuaries suggests an association between storm deities and mountains in Crete (Green 2003: 207).

Mountains are depicted anthropomorphically in Hittite art and were considered animate in Canaanite, Hittite, and Greek myth where they were thought to be able to move, sing, have emotional responses, procreate, and sleep (Clarke 1997). According to Late Bronze Age Ugaritic texts, mountains were directly sacrificed to and were invoked to safeguard treaties made with the kings of the Hatti and Hittites (Van Buren 1943; Yasur-Landau and Goshen 2014). In both Levantine and Greek religion, mountains were sites of theophany (della Dora and Terkenli 2012). Mountains also functioned as axes between upper, middle, and lower cosmological realms. This may have also been the case in Crete where mountain, rural, and cave sanctuaries suggest a tripartite division of the cosmos (Marinatos 2010). During the Classical period (480323 BCE) Cretan tradition associated the sacred mountains of Dikte and Jouktas with the 'Tomb of Zeus', a Cretan 'dying and rising' deity that was later Hellenised but who was probably based on a Near Eastern prototype such as Baal (Evans 1901; Postlethwaite 1999; Tully 2018b).

\section{Architecture}

The physical setting of Minoan architecture appears to reflect deliberate symbolic associations with mountains. The Minoan court-centered palaces are constructed along a roughly north-south orientation, often aligned to a prominent nearby mountain (figs. 3 and 4). The palace of Knossos is aligned with Mount Jouktas, the palace at Phaistos with Mount Ida, the palace at Malia with Mount Dikte, and the palace at Zakros with Mount Traostolos. The buildings grouped around the Central Court may have evoked mountains around a plain (Driessen 2004; Hitchcock 2007). Certain architectural features are also oriented toward solar, lunar, and astral movements, particularly toward the east and the rising sun (Goodison 2001). Many structures of apparently cultic function, including the rooms located on the west of the palatial central courts, were open

\footnotetext{
${ }^{6}$ It has been demonstrated that there was a religious koiné, or common language, in regard to deities and sacred natural features in the Bronze and Iron Age eastern Mediterranean as a result of continuous maritime contact (Watrous 1996: 82-89; Marinatos 2010; Tully 2018b).
} 
to the east and would consequently be the first illuminated by the rising sun each day whilst also overlooked by the nearby mountain (Shaw 1973). The evidently deliberate architectural alignment of the throne room at Knossos, located in the northern part of the west wing of the palace, would have caused the throne and whoever was seated upon it to be illuminated at specific times of the year, such as the winter solstice (Goodison 2001; Tully and Crooks in press).

\section{[Insert Figure 3 near here]}

Figure 3. The central court of the palace of Knossos aligned on Mount Juktas (photo by Caroline Tully).

\section{[Insert figure 4 near here]}

Figure 4. The central court of the palace of Phaistos aligned on Mount Ida (photo Caroline Tully).

The Knossos Throne is made of gypsum and features a mountain-shaped back, similar in outline to that depicted between the antithetic goats on the Peak Sanctuary Rhyton from Zakros. ${ }^{7}$ It is located in the Throne Room suite and is set against the middle of the north wall on the right as one enters from the Central Court of the palace (Evans 1936). ${ }^{8}$ A fresco of palm trees and wingless griffins decorates the wall surrounding the throne, while stone benches run along the walls on either side (fig. 5). Directly opposite the throne on the south side is a Lustral Basin, an architectural feature of uncertain function consisting of stairs descending into a sunken stonelined space that may represent a cave and have been used for purification, offerings and sacrifice (Evans 1936; S. Marinatos 1941; Tyree 1974; 2001; N. Marinatos 1984; Hitchcock 2007;

\footnotetext{
${ }^{7}$ This wavy mountain form also appears on a tray from the peak sanctuary of Jouktas (Karetsou 1981: Fig. 27).

${ }^{8}$ The suite dates back to the Protopalatial period and underwent four building phases between the Middle Minoan II and Late Minoan IIIA1-2 (ca. 1850-1330 BCE). The throne may have derived from a wooden prototype as is suggested by its carved curved legs, which suggest joinery. The throne may date to as early as the Late Minoan IA (1700-1580 BCE) as its back is slightly embedded into - and thus predates - the latest renovation of the wall plaster, which is usually dated to Late Minoan II-IIIA (1490-1370 BCE), but may be as early as Late Minoan IB (1580-1490 BCE). Evidence of a formal throne room in Bronze Age Crete is known only at Knossos although a group of rooms in Building A in Quartier Mu at Malia replicate the plan of the Throne Room at Knossos with slight variations. Stone seats similar to the Knossos throne have been found in several locations including near the shrine of Anemospilia on the slopes of Mount Jouktas, but no thrones have been found at other palaces (Rehak 1995, 98).
} 
Kopaka 2009). ${ }^{9}$ The Throne Room had the capacity to hold only around thirty people, so the throne would have had a restricted and exclusive audience (Evans 1936; Marinatos 2010). ${ }^{10}$ Thus, the architectural design of the Throne Room at Knossos instantiates the Minoan axis mundi, in which the Minoan elite figure is enthroned upon a mountainous seat of power and positioned at the centre of the Minoan tripartite cosmology, consisting of a sacred mountain, terrestrial plain, and subterranean caves. ${ }^{11}$ In this sense, the built environment and the social fabric itself is construed as part of the natural order, as is the status of the enthroned figure.

\section{[Insert figure 5 near here]}

Figure 5. The Knossos Throne (drawing by Anna Crooks).

The shape of the Knossos Throne back is also morphologically similar to the baetyls at the palatial sites of Gournia and Galatas which suggests that such wavy-edged stones may represent stylised mountains (Koehl 2006; Crooks 2013; Crooks et al. 2016) (figs. 6 and 7). An association between baetyls and mountains may be evident at the peak sanctuary of Atsipadhes Korakias, where the cult area features a dense scatter of waterworn pebbles around a depression entirely free of finds and surrounded by numerous pottery sherds. The excavator suggested that a focal cult object, possibly a baetyl, may have originally stood in this depression (Peatfield 1994). The Minoan-style peak sanctuary at Leska on the island of Kythera also has a pyramidal baetylic rock at its summit (Georgiadis 2014; Tully and Crooks in press). That baetyls were prominent features within palatial architecture is evident from the palace at Malia where in the northwest corner of the Central Court, directly before a raised platform (loggia), a relatively small baetyl with a prominent cupule, possibly for deposition of offerings, is embedded into the packed earth of the court (Charpouthier et. al. 1962; Pelon et. al. 1980; 2002; Van Effenterre 1980; Warren 1990; Crooks 2013) (fig. 8). The center of the court is marked by a sunken altar, and its western sides are flanked by rooms of likely cultic function. These include a pillar crypt, which can be interpreted as an architectonic representation of a cave, the pillar evoking the stalagmites and stalactites which are a common feature of Minoan caves, and Room XVI-1 with a stepped platform and kernos (a stone with multiple cupules for offerings). Directly west of the baetyl, the raised loggia may have functioned as a platform or stage upon which prominent individuals stood, either in order to observe activities taking place within the court and in the vicinity of the baetyl or to be observed. A direct alignment may be traced between the raised loggia, the baetyl,

\footnotetext{
${ }^{9}$ Cave sanctuaries constitute another type of Minoan cult site.

${ }^{10}$ The number of people viewing the Knossos throne would have increased if the audience moved through the Throne Room and then departed, making way for a fresh audience.

${ }^{11}$ It is not known whether Minoan Crete was ruled hierarchically by a theocratic monarchy, heterarchically by factions, or consisted of matrilineal and matrilocal corporations; however, the presence of elites is agreed upon (Rehak 1995; Marinatos 2010; Hamilakis 2002; Schoep 2002a, 2002b; Driessen 2010a; 2010b; 2012; 2013; Tully and Crooks in press).
} 
and the mountains beyond the palace from which a deliberate association between the palace and the landscape may be inferred.

\section{[Insert figure 6 near here]}

Figure 6. The baetyl at Gournia (photo by Sam Crooks).

\section{[Insert figure 7 near here]}

Figure 7. The baetyl at Galatas (photo by Sam Crooks).

\section{[Insert figure 8 near here]}

Figure 8. The baetyl in the central court of the palace at Malia (photo by Sam Crooks).

\section{Iconography}

The wavy-edged mountain form, as seen on the back of the Knossos Throne and depicted on the Zakros Rhyton, finds further representation in elite female costume at Knossos, where the decoration on faience votive dresses from the Temple Repositories evokes the mountain form (Evans 1921; Chapin 2008; Tully and Crooks in press) (fig. 9). The elaborate skirts characteristic of Neopalatial elite female costume may also have referenced mountains - their flounced and layered appearance evoking a jagged mountainous profile (figs. 10 and 11). Similar skirts are worn by Hittite mountain deities (Chapin 2008; Tully 2018b). The Knossos Throne is traditionally thought to have been occupied by a priestess performing the role of a deity because in Aegean iconography griffins are more commonly associated with female, rather than male, figures (Reusch 1958). ${ }^{12}$

\section{[Insert figure 9 near here]}

Figure 9. Faience dresses with mountain design (drawing by Anne P. Chapin).

\section{[Insert figure 10 near here]}

Figure 10. Minoan 'Snake Votary' wearing a flounced skirt (drawing by Anne P. Chapin).

\footnotetext{
${ }^{12}$ Evans (1936) thought that the carved depression in the seat was more suited to female anatomy, but later decided that the throne belonged to King Minos. Hitchcock (2010) proposes an empty throne, while Marinatos (2010) places a king on the throne.
} 


\section{[Insert figure 11 near here]}

Figure 11. Minoan female figure wearing a flounced skirt (drawing by Anne P. Chapin).

Various cult structures depicted in iconography, interpreted as representative and metonymic of mountains, are associated primarily with female figures. Examples are found in the two-dimensional art forms of glyptic and fresco painting, and in carved stone vases and carved ivory. Glyptic art, consisting of carved seal stones, engraved metal signet rings and the clay impressions (sealings) that the seals were used to produce, is the most extensive body of Aegean Bronze Age representational art. Glyptic iconography depicts images of powerful male and female figures standing upon mountains overlooking towns and palaces (figs. 12 and 13), and exclusively female figures sitting on rocky outcrops, on seats with rocky backs, and on stepped structures (figs, 14, 15 and 16), all of which may function as abbreviated representations of mountains (Tully 2018b; Tully and Crooks in press). The female figure may represent Potnia, mentioned in the Linear B texts, whose name means 'she who has power', possibly indicating a goddess or queen (Rehak 1995, 117). Female figures sitting on rocks are particularly evocative of the iconography of the Mesopotamian mountain goddess, Ninhursag (fig. 17), patron goddess of the Sumerian kings (Westenholz 2002).

\section{[Insert figure 12 near here]}

Figure 12. Drawing of a clay sealing from Knossos depicting a female figure standing on a mountain (Gill et. al. 2002, no. 256).

\section{Insert figure 13 near here]}

Figure 13. Drawing of a clay sealing from Khania depicting a male figure standing on a mountain (Hallager 1985, fig. 11).

\section{[Insert figure 14 near here]}

Figure 14. Drawing of a stone seal from Crete depicting a female figure seated on a rocky outcrop (Gill et al. 2002, no. 239).

\section{[Insert figure 15 near here]}

Figure 15. Drawing of a gold ring from Mycenae depicting a female figure seated on a chair with a rocky back (Xenaki-Sakellariou 1964, no. 101).

\section{[Insert figure 16 near here]}


Figure 16. Drawing of a clay sealing from Khania depicting a female figure seated on stepped openwork platform (Pini 1992, no. 177).

\section{[Insert figure 17 near here]}

Figure 17. Drawing of the goddess Ninhursag from a Late Akkadian (ca. 2254-2154 BCE) cylinder seal (Dalit Weinblatt-Krausz).

Triangular cult structures depicted in iconography, which are sat upon exclusively by female figures, including stepped ashlar shrines, tripartite shrines, and constructed openwork platforms may have been architectonic evocations of the ascending mountain form (Tully 2018b; Tully and Crooks in press). Constructed openwork platforms are stepped structures consisting of vertical and horizontal elements which usually have at least two or more levels that step inwards as they ascend (fig. 18). Detailed examples of such structures show that the horizontal components often rest upon incurved altars. ${ }^{13}$ The shape made by incurved altars underneath constructed openwork platforms correlates to the split-rosette pattern as seen on either side of the Knossos Throne (Evans 1928), as well as other examples featuring seated elite females such as the Tiryns Ring (fig. 19). Such a pattern also appears on the border of the central female figure's dress in the Procession Fresco in the West Corridor of the Palace of Knossos (Marinatos 2010) (fig. 20). A further association between incurved altars, females, and mountains is evident on an Aegean style ivory pyxis fragment from Ugarit that depicts a female figure seated directly on an incurved altar which is in turn situated on a mountain (fig. 21). The figure is feeding two caprids in an arrangement similar to the mountain between antithetic goats depicted on the Zakros Rhyton.

\section{[Insert figure 18 near here]}

Figure 18. Constructed openwork platform (after Doumas 1992, 295).

\section{[Insert figure 19 near here]}

Figure 19. Drawing of a gold ring from Tiryns depicting a female figure seated on a throne underneath of which is the split rosette pattern (Xenaki-Sakellariou 1964, no. 179).

\section{[Insert figure 20 near here]}

Figure 20. Hem of female figure's dress from the Corridor of the Processions fresco at Knossos (after Evans 1928, fig. 456).

${ }^{13}$ Such an altar can be seen on the Zakros Rhyton above. 


\section{[Insert figure 21 near here]}

Figure 21. Ivory pyxis lid from Ugarit (Louvre AO 11601).

Constructed openwork platforms functioned as prefabricated stages that could be assembled, disassembled, and moved around for use in the performance of religious spectacles (Palyvou 2006). That such structures were linked to rock and possibly mountains can be seen in the image of the female figure depicted in the fresco on the northern wall of Room 3a at Xeste 3 on the island of Thera (Santorini) seated on such a platform. Directly below her a female figure with wounded foot is sitting upon rocks (Doumas 1992) (fig. 22). The positioning of these two scenes suggests a symbolic correlation between these features. ${ }^{14}$

\section{[Insert figure 22 near here]}

Figure 22. Drawing of fresco paintings from the north wall, ground and first levels, Building Xeste 3 at Thera, depicting female figures seated upon a constructed openwork platform and on a rocky outcrop (Doumas 1992, 295).

All examples of constructed openwork platforms are depicted with female figures sitting on top of them and two examples are surmounted by trees, the interchangability between females and trees being a feature of Aegean and eastern Mediterranean art and religion (Tully 2018b). The surrounding vegetation and rocks in many iconographic representations of these platforms suggests that they were used outdoors and may have been intended to evoke ritual performance at a peak sanctuary (Rehak 1997). The presence of crocus flowers in the fresco examples reference a mountainous location as is evident from their depiction in the vicinity of the peak sanctuary on the Zakros Rhyton. The fact that only women pick crocus flowers in Minoan iconography suggests a further association between sacred mountains and females (Chapin 1995). While depicted as occurring in natural locations, the ritual performances in which such platforms were used took place at urban sites (Rehak 1997; Tully 2018b; Tully and Crooks in press).

Evidence for a constructed openwork platform has been found at the palatial site of Archanes located in central Crete below the peak sanctuary of Jouktas. Four incurved altars found packed tightly together against a column in the side of an imposing entranceway into an antechamber, arranged so that their tops made a square formation, may have formed a larger altar or platform base for a seat (Sakellarakis and Sapouna-Sakalleraki 1991) (fig. 23). Such a platform may have served as a structure upon which a female figure sat as part of a ritual

\footnotetext{
${ }^{14}$ As noted by Rehak (1995, 106, Fig. XXXVIIc).
} 
performance that was an important feature or focus of public gatherings and processions. The image of a female figure seated upon a stepped architectonic structure would evoke peak sanctuary ritual as well as the actual mountain itself; the combination of the female figure and the platform manifesting the mountain in a manner similar to the female figure sitting on the Knossos throne with its mountain-shaped back. The evident association between females, rocky seats, and stepped cult structures, in conjunction with the mountain forms depicted on female votive garments, demonstrates an association between females, mountains, and power during the Neopalatial period in Crete.

\section{[Insert figure 23 near here]}

Figure 23. Incurved altars at Archanes Tourkogeitonia, view north (photo by O. Tausch).

In conclusion, the Minoans perceived a tripartite ontology focussed on mountains. Minoan peak sanctuaries were established during the Middle Minoan period when pastoralists were forced upland in response to environmental change. Mountains, as sources of water, were associated with fertility and sustenance. These qualities were appropriated by Neopalatial elites and symbolically replicated through architecture, iconography, and performance in order to naturalise their authority. Mountains and the cult sites located upon them were evoked through stylised form within urban locations and associated with female figures. While elite males were linked with the actual peak sanctuaries, it has been demonstrated here that elite females brought the associations of mountain cult sites down to the palaces and their networks through ritual performance in conjunction with architectonic structures and special costumes. During theatrical events involving elite female figures seated on real and symbolic mountains, and wearing mountain-evoking garments, the privileged status of Minoan elites would have been reiterated and recreated through performance. While usurping the awesome and powerful qualities of mountains, their symbolic presence in urban palatial locations suggests that Minoan elites symbolically domesticated mountains and presented a reciprocal relationship between this aspect of the animate landscape and themselves. In Minoan ritual performance, artistic and architectural representations of the sacred mountainous landscape signified and symbolised power relations and this functioned as an instrument of elite cultural hegemony. Rather than signifying a benign love of nature, Neopalatial elite ritual in conjunction with symbolic mountains functioned to materialise ideology and define political reality.

\section{$\underline{\text { References }}$}


Arnott, Robert. 1996. 'Healing and Medicine in the Aegean Bronze Age', Journal of Royal Society of Medicine 89: 265-270.

Ashmore, Wendy and A. Bernard (eds.) 1999. Archaeologies of landscape: contemporary perspectives (Malden: Blackwell).

Avner, Uzi. 1993. 'Masseboth sites in the Negev and Sinai and their significance', in J. Aviram (ed.) Second International Congress on Biblical Archaeology in Jerusalem 1990 (Jerusalem: Israel Exploration Society): 166-181.

Barrett, John C. 2003. 'Chronologies of landscape,' in P.J. Ucko and R. Layton (eds.) The Archaeology and Anthropology of Landscape (London: Routledge): 21-30.

Bender, Barbara. 1998. Stonehenge: Making Space. Oxford: Berg.

—- Hamilton, Sue and Tilley, Christopher. 1997. 'Leskernick: stone worlds; alternative narratives; nested landscapes,' Proceedings of the Prehistoric Society 63: 147-75.

Bloch, Maurice and Jonathon Parry. 1982. Death and the Regeneration of Life (Cambridge: Cambridge University Press).

Blomberg, Mary and Göran Henriksson. 2016. 'The Discovery of Minoan Astronomy and its debt to Robin Hägg', Journal of Prehistoric Religion 25: 64-77.

Casey, Edward S. 1996. 'How to get from space to place in a fairly short stretch of time:

phenomenological prolegomena,' in S. Feld and K.H. Basso (eds.) Senses of Place (Santa Fe: SAR Press): 13-52.

- 2008. 'Place in Landscape Archaeology: A Western Philosophical Prelude,' in B. David and J. Thomas (eds.) Handbook of Landscape Archaeology (Walnut Creek: Left Coast Press): 44-50.

Chapin, A. P. 1995. Landscape and Space in Aegean Bronze Age Art (Unpublished PhD Thesis, University of North Carolina at Chapel Hill).

Chapin, A. P. 2008. 'The lady of the landscape. An investigation of Aegean costuming and the Xeste 3 frescoes', in C. Colburn and M. Heyn (eds.), Reading a Dynamic Canvas. Adornment in the Ancient Mediterranean World (Newcastle: Scholars Press): 48-83.

Chapman, John 1997. 'Places as Timemarks - the Social Construction of Prehistoric Landscapes in Eastern Hungary,' in G. Nash (ed.) Semiotics of Landscape: Archaeology of Mind (Oxford: Archaeopress): 31-45.

- 2008. 'Object Fragmentation and Past Landscapes,' in B. David and J. Thomas (eds.) Handbook of Landscape Archaeology (Walnut Creek: Left Coast Press): 187-201.

- 2012. 'The Negotiation of Place Value in the Landscape,' in J.K. Papadopoulos and G. Urton (eds.) The Construction of Value in the Ancient World (Los Angeles: Cotsen Institute of Archaeology, University of California): 66-89. 
Charpouthier, Fernand, Pierre Demargne and André Dessenne. 1962. Fouilles exécutées à Malia IV: Exploration du Palais; Bordure Méridionale et recherches complémentaires (1929-1935 et 1946-1969). Études crétoises 12 (Paris: Libraire Orientaliste Paul Geuthner).

Clarke, Michael. 1997. 'Gods and Mountains in Greek Myth and Poetry,' in A. B. Lloyd (ed.) What is a God? Studies in the nature of Greek Divinity (London: Duckworth): 65-80.

Clifford, Richard J. 1972. The Cosmic Mountain in Canaan and the Old Testament (Cambridge: Harvard University Press).

Coben, Lawrence. 2006. 'Other Cuzcos: replicated theaters of Inka Power', in T. Inomata and L.S. Coben (eds.) Archaeology of performance: theaters of power, community, and politics (Lanham: Altamira Press): 223-259.

Crooks, Sam. 2012. 'Cult Stones of Ancient Cyprus', Journal of Prehistoric Religion XXIII: 2544.

2013. What are these Queer Stones? Baetyls: Epistemology of a Minoan Fetish (Oxford: Archaeopress).

- In press a. 'Natural Landscapes', in L. Hitchcock and B. Davis (eds.) A Companion to Aegean Art and Architecture (Hoboken, Blackwell).

—. In press b. 'Your Place or Mine? Values in Place in Middle Chalcolithic Cyprus: a view from Souskiou', in E. Margaritis and A. McCarthy (eds.) Environment, Landscape and Society: Diachronic Perspectives on Settlement Patterns in Cyprus (ASOR: Boston).

—., Caroline J. Tully and Louise A. Hitchcock. 2016. 'Numinous Tree and Stone: Reanimating the Minoan Landscape,' in E. Alram-Stern, F. Blakolmer, S. Deger-Jalkotzy, R. Laffineur and J. Weilhartner (eds.) METAPHYSIS: Ritual, Myth and Symbolism in the Aegean Bronze Age. Aegaeum 39 (Leuven: Peeters): 157-64.

Crowley, Janice L. 1989. The Aegean and the East: An Investigation into the Transference of Artistic Motifs between the Aegean, Egypt, and the Near East in the Bronze Age (Jonsered: Paul Åström).

Davaras, Costis. 2010. 'One Minoan Peak Sanctuary Less: The Case of Thylakas', in O.

Krzsyzkowska (ed.) Cretan Offerings: Studies in Honour of Peter Warren (London: British School at Athens): 71-88.

Davis, Brent E. 2014. Minoan Stone Vessels with Linear A Inscriptions. Aegaeum 36 (Leuven: Peeters).

della Dora, Veronica and Theano S. Terkenli. 2012. 'Cultural Geographies', in Ioannis N. Vogiatzakis (ed.) Mediterranean Mountain Environments (Oxford: Wiley-Blackwell): 137-157. Doumas, Christos. 1992. The Wall Paintings of Thera (Athens: Thera Foundation). 
Driessen, Jan. 2004. 'The Central Court of the Palace at Knossos', in G. Cadogan, E. Hatzaki and A. Vasilakis (eds.) Knossos: Palace, City, State (London: British School at Athens): 75-82. _., Ilse Schoep and Robert Laffineur (eds.). 2002. Monuments of Minos: Rethinking the Minoan palaces. Proceedings of the International Workshop "Crete of the Hundred Palaces?" Université Catholique de Louvain-la-Neuve, 14-15 December 2001. Aegaeum 23 (Liège: Université de Liège).

—. 2010a. 'Spirit of Place. Minoan Houses as Major Actors', in D. J. Pullen (ed.) Political Economies of the Aegean Bronze Age (Oxford: Oxbow): 35-65.

. 2010b. 'The Goddess and the Skull. Some Observations on Group Identity in Prepalatial Crete', in O. Krzyszkowska (ed.) Cretan Offerings. Studies in honour of Peter M. Warren (London: British School at Athens): 107-117.

. 2012. 'A Matrilocal House Society in Pre-and Protopalatial Crete ?', in I. Schoep, P. Tomkins and J. Driessen (eds) Back to the Beginning: Reassessing Social and Political Complexity on Crete during the Early and Middle Bronze Age (Oxford: Oxbow): 358-383.

- 2013. 'Chercher la femme. Identifying Minoan Gender Relations in the Built Environment', in U. Günkel-Maschek and D. Panagiotopoulos (eds) Minoan Realities. Proceedings of a workshop held in Heidelberg, November 2009, (Aegis 5) (Louvain: UCL Presses Universitaires de Louvain): 141-164.

Eller, Cynthia. 2012. 'Two Knights and a Goddess: Sir Arthur Evans, Sir James George Frazer, and the Invention of Minoan Religion', Journal of Mediterranean Archaeology 25: 75-98.

Evans, Arthur J. 1901. 'Mycenaean Tree and Pillar Cult and its Mediterranean Relations', The Journal of Hellenic Studies 21: 99-204.

_. 1921; 1928; 1930; 1936. The Palace of Minos I. London: Macmillan.

Faure, Paul. 1969. 'Sur trois sortes de sanctuaries crétois', Bulletin de Correspondence Hellénique 93: 174-213.

Fowler, Chris. 2008. 'Landscape and Personhood', in B. David and J. Thomas (eds.) Handbook of Landscape Archaeology (Walnut Creek: Left Coast Press): 291-299.

Friedman, Jonathan and Michael Rowlands. 1978. Evolution of Social Systems (London: Duckworth).

Geertz, Clifford. 1980. Negara: The Theatre State in Nineteenth Century Bali (Princeton: Princeton University Press).

Georgiadis, Mercourios. 2012. 'Leska: a new peak sanctuary on the island of Kythera', Journal of Prehistoric Religion 23: 7-23.

- 2014. 'The physical environment and beliefs at Leska, a new peak sanctuary discovered at Kythera', in G. Touchais, R. Laffineur, F. Rougemont (eds.) Physis. L'Environment Naturel et 
la Relation Homme-Millieu dans le Monde Égéen Protohistorique. Aegaeum 37 (Université de Liège: Leuven): 481-484.

Gere, Cathy. 2009. Knossos and the Prophets of Modernism (Chicago: University of Chicago Press).

Gill, Margaret A.V., Walter Müller and Ingo Pini (eds.) 2002. Corpus der Minoischen und Mykenischen Siegel, II: Iraklion Archäologisches Museen, 8: Die Siegelabdrücke von Knossos unter Einbeziehung von Funden aus andren Museun (Mainz: Philipp von Zabern).

Goodison, Lucy. 2001. 'From Tholos Tomb to Throne Room: Perceptions of the Sun in Minoan Ritual', in R. Laffineur and W.D. Niemeier (eds.) Potnia: Deities and Religion in the Aegean Bronze Age. Aegaeum 22 (Liège: Université de Liege): 77-88.

—. 2012. "Nature," the Minoans and Embodied Spiritualities', in K. Rountree, C. Morris and A. Peatfield Archaeology of Spiritualities (New York: Springer) 207-225.

Graesser, Carl F. 1972. 'Standing stones in ancient Palestine', Biblical Archaeologist 35: 34-63.

Green, Alberto. 2003. The Storm God in the Ancient Near East (Winona Lakes: Eisenbrauns).

Groenewegen-Frankfort, Henriette A. 1951. Arrest and Movement: An Essay on Space and Time in the Representational Art of the Ancient Near East (London: Faber and Faber).

Hallager, Erik. 1985. The Master Impression: a clay sealing from the Greek-Swedish excavations at Kastelli, Khania (Göteborg: Åströms).

Hamilakis, Yannis. 2002. 'Too Many Chiefs?: Factional Competition in Neopalatial Crete,' in J. Driessen, I. Schoep, and R. Laffineur (eds.) Monuments of Minos. Rethinking the Minoan Palaces, Aegaeum 23 (Liège: Université de Liège): 179-199.

Haysom, Matthew. 2018. 'Mass and elite in Minoan peak sanctuaries,' in G, Vavouranakis, K. Kopanais, and C. Kanellopoulos (eds.) Popular Religion and Ritual in prehistoric and ancient Greece and the eastern Mediterranean (Oxford: Archaeopress).

Heidegger, Martin. 1971. Poetry, Language, Thought (New York: Harper and Row).

Herva, Vesa-Pekka. 2006. 'Flower Lovers, After All? Rethinking Religion and HumanEnvironment Relations in Minoan Crete', World Archaeology 38: 586-598.

Hicks, Dan. 2010. 'The Material-Cultural Turn: Event and Effect,' in D. Hicks and M.C. Beaudry (eds.) The Oxford Handbook of Material Culture Studies (Oxford: Oxford University Press): 25-98.

Hoskins, W.G. 1955. The Making of the English Landscape (London: Hodder \& Stoughton).

Hitchcock, Louise A. 2007. 'Naturalizing the Cultural: architectonicized landscape as ideology in Minoan Crete', in R. Westgate, N. Fisher and J. Whitley (eds.) Building Communities: House, Settlement and Society in the Aegean and Beyond, Cardiff University, April 17-21, 2001 (London: British School at Athens): 91-97. 
- 2010. 'The big nowhere. A master of animals in the throne room at Knossos?', in D. Counts and B. Arnold (eds.) The Master of Animals in Old World Iconography (Budapest: Archaeolingua): 107-118.

Hodder, Ian and Scott Hutson. 2003. Reading the Past: Current Approaches to Interpretation in Archaeology (Cambridge: Cambridge University Press).

Huntington, Richard and Peter Metcalf. 1979. Celebrations of Death: The Anthropology of Mortuary Ritual (Cambridge: Cambridge University Press).

Ingold, Timothy. 1993. 'The temporality of the landscape', World Archaeology 25: 152-174.

Jones, Donald W. 1999. Peak Sanctuaries and Sacred Caves in Minoan Crete: Comparison of Artifacts (Jonsered: Åströms Förlag).

Kan, Sergei. 1989. Symbolic Immortality: The Tlingit Potlatch of the Nineteenth Century (University of Washington Press: Seattle).

Knapp, A. Bernard. 1999. 'Ideational and Industrial Landscape on Prehistoric Cyprus,' in W. Ashmore and A.B. Knapp (eds.) Archaeologies of Landscape: Contemporary Perspectives (Oxford: Blackwell): 229-252.

Koehl, Robert B. 2006. Aegean Bronze Age Rhyta (Philadelphia: INSTAP Academic Press).

Kopaka, Katerina. 2009. 'Mothers in Aegean Stratigraphies: the dawn of ever-continuing engendered life cycles,' in K. Kopaka (ed.) FYLO. Engendering Prehistoric 'Stratigraphies' in the Aegean and the Mediterranean. Aegaeum 30 (Université de Liège: Liège): 184-194.

Kosiba, Steve. 'Emplacing Value, Cultivating Order: Places of Conversion and Practices of Subordination Throughout Early Inka State Formation (Cuzco, Peru), in J.K. Papadopoulos and G. Urton (eds.) The Construction of Value in the Ancient World (Los Angeles: Cotsen Institute of Archaeology, University of California: 97-127.

Kyriakidis, Evangelos. 2005. Ritual in the Bronze Age Aegean: The Minoan Peak Sanctuaries (Duckworth: London).

Macdonald, Colin F. 2017. 'Punctuation in palatial prehistory: earthquakes as the stratigraphical markers of the $18^{\text {th }}$ to $15^{\text {th }}$ centuries BC in central Crete,' in S. Jusseret and Manuel Sintubin (eds.) Minoan Earthquakes: Breaking the Myth through Interdisciplinarity (Leuven University Press: Leuven) 327-358.

Manning, Sturt W. 2010. 'Chronology and Terminology', in Eric H. Cline (ed.) The Oxford Handbook of the Bronze Age Aegean (Oxford: Oxford University Press): 11-28.

Marinatos, Nanno. 1984. Art and Religion in Thera: Reconstructing a Bronze Age Society (Athens: D. \& I. Mathioulakis). 1993. Minoan Religion: Ritual, Image, and Symbol (Columbia: University of South Carolina Press). 
-2010. Minoan Kingship and the Solar Goddess. A Near Eastern Koine (Urbana: University of Illinois Press).

Marinatos, Spyridon. 1941. 'The cult of Cretan caves', Review of Religion 5: 129-136.

McEnroe, John. 1995. 'Sir Arthur Evans and Edwardian Archaeology'. Classical Bulletin 71: 318.

MacGillivray, Joseph A. 2000. Minotaur: Sir Arthur Evans and the Archaeology of Minoan Myth (New York: Hill \& Wang).

Mitchell, William J. T. 2002. Landscape and Power (Chicago: University of Chicago Press).

Momigliano, Nicoletta. 2006. 'Sir Arthur Evans, Greek Myths and the Minoans', in P. Darque, M. Fotiadis, O. Polychronopoulou (eds.) Mythos: Le Préhistoire égéenne du XIX ${ }^{e}$ au XXI siècle après J.-C. Actes de la table ronde internationale d'Athènes (21-23 novembre 2002) (Athens: Bulletin de Correspondence Hellénique): 73-80.

Moody, Jennifer M. 2009. 'Environmental Change and Minoan Sacred Landscapes', A. L. D'Agata and A. van de Moortel (eds.) Archaeologies of Cult: Essays on Ritual and Cult in Honour of Geraldine C. Gesell (Princeton: American School of Classical Studies at Athens): 241-249.

Nowicki, Krystof. 1994. 'Some remarks on the Pre- and Protopalatial peak sanctuaries in Crete', Aegean Archaeology 1: 31-48.

— 2007. 'Some Remarks on New Peak Sanctuaries in Crete: The Topography of Ritual Areas and their Relationship with Settlements', Jarbuch des Deutschen Archäologischen Instituts 122: 1-31.

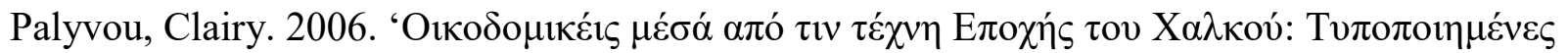

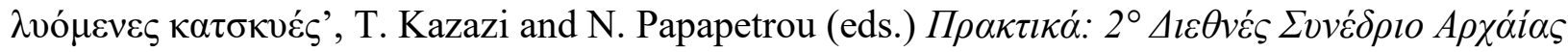

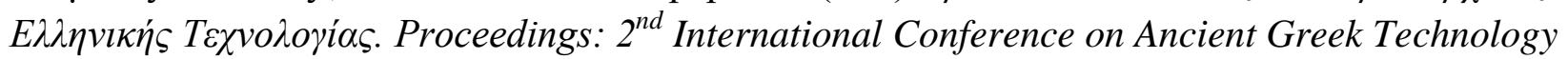
(Athens: EMAET): 417-424.

Peatfield, Alan D. 1983. 'The topography of Minoan peak sanctuaries', Annual of the British School at Athens 78: 273-279.

—. 1987. 'Palace and peak: the political and religious relationship between palaces and peak sanctuaries', R. Hägg and N. Marinatos (eds.) The Function of the Minoan Palaces. Proceedings of the Fourth International Symposium at the Swedish Institute in Athens (June 1984)

(Stockholm: Swedish Institute in Athens): 89-93.

_ 1990. 'Minoan peak sanctuaries: History and society', Opuscula Atheniensia 18: 117-31.

_. 1994. "After the "Big Bang" - What? Or Minoan symbols and shrines beyond palatial collapse', S.E. Alcock and R. Osborne (eds.) Placing the Gods: Sanctuaries and Sacred Space in Greece (Oxford: Clarendon Press): 19-36. 
- 2001. 'Divinity and Performance on Minoan Peak Sanctuaries', R. Laffineur and W.D. Niemeier (eds.) Potnia: Deities and Religion in the Aegean Bronze Age. Aegaeum 22 (Liège: Université de Liège): 51-55.

- 2009. 'The Topography of Minoan Peak Sanctuaries Revisited', in A.L. D'Agata and A. Van de Moortel (eds.) Archaeologies of Cult: Essays on Ritual and Cult in Crete in Honor of Geraldine C. Gesell (Princeton: American School of Classical Studies at Athens): 251-259.

Peirce, Charles S. 1935. Collected Papers of Charles Sanders Peirce (Cambridge: Harvard University Press).

Pelon, Olivier, Elga Andersen and Jean-Pierre Olivier. 1980. Le Palais de Mallia V. Études crétoises 25 (Paris: Paul Geuthner).

—. 2002. 'Contribution du Palais de Malia à l'Étude et à l'Interprétation des "Palais"

Minoens', in J. Driessen, I. Schoep, and R. Laffineur (eds.), Monuments of Minos: Rethinking the Minoan Palaces (Liège: Université de Liège): 111-121.

Pini, Ingo. 1992. CMS V Suppl. 1A Kleinere Griechische Sammlungen. Ägina - Korinth (Berlin: Gebr. Mann).

Platon, Nicolaos. 1951. KrChron 5: 96-160.

Postlethwaite, T. Neville. 1999. "The Death of Zeus Kretagenes.” Kernos 12: 85-98.

Rackham, Oliver and Jennifer Moody. 1996. The Making of the Cretan Landscape (Manchester: Manchester University Press).

Rehak, Paul. 1995. 'Enthroned Figures in Aegean Art and the Function of the Mycenaean Megaron', in P. Rehak (ed.) The Role of the Ruler in the Prehistoric Aegean. Proceedings of a Panel Discussion presented at the Annual Meeting of the Archaeological Institute of America New Orleans Louisiana 29 December 1992. With Additions. Aegaeum 11 (Liège: Université de Liège): 95-117.

- 1997. 'The role of religious painting in the function of the Minoan villa: the case of Ayia Triadha', in R. Hägg (ed.) The Function of the "Minoan Villa” (Stockholm: Paul Åström): 163175.

and Younger. 1998. 'Review of Aegean Prehistory VII: Neopalatial, Final Palatial and Postpalatial Crete', American Journal of Archaeology 102: 91-173.

Reusch, Helga. 1958. 'Zum wandschmuck des thronsaales in Knossos', in E. Grumach (ed.) Minoica. Festschrift zum 80. Geburstag von Johannes Sundwall (Berlin 1958): 344-58.

Rutkowski, Bogdan. 1986. The Cult Places of the Aegean (New Haven and London: Yale University Press).

Sakellarakis, Yannis A. 1996. 'Minoan religious influence in the Aegean. The case of Kythera', Annual of the British School at Athens 91: 81-99. 
—. and E. Sapouna-Sakalleraki. 1991. Archanes (Athens: Ekdotike Athenon).

Shanks, Michael and Christopher Tilley. 1982. 'Ideology, Symbolic Power and Ritual Communication: A Reinterpretation of Neolithic Mortuary Practices', in I. Hodder (ed.)

Symbolic and Structural Archaeology (Cambridge: Cambridge University Press): 129-54.

Shaw, Joseph W. 1973. 'The Orientation of the Minoan Palaces', Antichità Cretesi: Studi in onore di Doro Levi (Catania, Sicily: University of Catania): 47-59.

- 1978. 'Evidence for the Minoan Tripartite Shrine', American Journal of Archaeology 82.4: 429-448.

Schoep, Ilse. 2002a. 'Social and Political Organization on Crete in the Proto-Palatial Period: The Case of Middle Minoan II Malia,' Journal of Mediterranean Archaeology 15.1: 101-132.

- 2002b. 'The State of the Minoan Palaces or the Minoan Palace-State?,' in J. Driessen, I. Schoep, and R. Laffineur (eds.) Monuments of Minos. Rethinking the Minoan Palaces, Aegaeum 23 (Liège: Université de Liège): 15-33.

Soar, Kathryn. 2009. 'Old Bulls, New Tricks: The Reinvention of a Minoan Tradition', on M. Georgiadis and C. Gallou (eds.) The Past in the Past: The Significance of Memory and Tradition in the Transmission of Culture (Oxford: Archaeopress): 16-27.

- 2014. 'Sects and the City: factional ideologies in representations of performance from Bronze Age Crete’, World Archaeology 46: 224-241.

Strathern, Andrew. 1996. 'Sacrifice and Sociality. A Duna ritual track', C. Ballard and L. Goldman Fluid Ontologies: Myth, Ritual and philosophy in the highlands of Papua New Guinea (Westport: Bergin \& Garvey): 31-42.

Thomas, Julian. 2008. 'Archaeology, Landscape, and Dwelling,' in B. David and J. Thomas (eds.) Handbook of Landscape Archaeology (Walnut Creek: Left Coast Press): 300-306.

Tilley, Christopher 1994. A Phenomenology of Landscape: places, paths and monuments (Oxford: Berg).

- 2008. 'Phenomenological Approaches to Landscape Archaeology', in B. David and J.

Thomas (eds.) Handbook of Landscape Archaeology (Walnut Creek: Left Coast Press): 271-276.

Tomkins, Peter. 2010. 'Neolithic antecedents', in E. Cline (ed.) The Oxford Handbook of the

Bronze Age Aegean (Oxford: Oxford University Press): 31-49.

Trigger, Bruce G. 2006. A History of Archaeological Thought (Cambridge: Cambridge University Press).

Tuan, Yi-Fu. 1977. Space and Place: The Perspective Experience (Minneapolis: University of Minnesota Press).

Tully, C. 2018a. 'Thalassocratic Charms: Trees, Boats, Women and the Sea in Minoan Glyptic Art', Proceedings of the $12^{\text {th }}$ International Congress of Cretan Studies, 2016, Heraklion, Crete. 
Tully, C. 2018b. The Cultic Life of Trees in the Prehistoric Aegean, Levant, Egypt and Cyprus. Aegaeum 42 (Peeters: Leuven).

—. and S. Crooks. 2015. 'Dropping Ecstasy? Minoan Cult and the Tropes of Shamanism', Time and Mind: The Journal of Archaeology, Consciousness and Culture 8.2: 129-158.

—. In Press. 'Enthroned Upon Mountains: Iconography and the Construction of Power in the Aegean Bronze Age', in L. Naeh and D. B. Gilboa (eds.) The Throne in Art and Archaeology: From the Dawn of the Ancient Near East Until the Late Medieval Period (Vienna: OREA).

Tyree, Loeta. 1974. Cretan Sacred Caves: Archaeological Evidence (Unpublished PhD dissertation, University of Missouri at Columbia. Ann Arbor: University Microfilms).

—. 2001. 'Diachronic Changes in Minoan Cave Cult', in R. Laffineur and W.D. Niemeier (eds.) Potnia: Deities and Religion in the Aegean Bronze Age. Aegaeum 22 (Liège: Université de Liège): $39-50$.

Van Buren, E. Douglas. 1943. 'Mountain Gods', Orientalia 12: 76-84.

Van Effenterre, H. 1980. La Palais De Mallia: Et La Cité Minoenne. I - II. Pubblicazioni Dell' Instituto Per Gli Studi Micenei Ed Egeo-Anatolici Del Consiglio Nazionale Delle Ricerche. Rome: Edizioni Dell'Ateneo.

Warren, Peter. 1988. Minoan Religion as Ritual Action [SIMA-PB 72]. Göteborg: P Åströms.

Warren, P. 1990. 'Of Baetyls', Opuscula Athiensia 18.14: 193-206.

Watrous, L.V. 1995. Some Observations on Minoan Peak Sanctuaries. In Politeia: Society and State in the Aegean Bronze Age [Aegaeum 12], edited by R. Laffineur and W.-D. Niemeier, 393403. Liège: Université de Liège; Austin: University of Texas.

Watrous, Livingston V. 1996. The Cave Sanctuary of Zeus at Psychro: A Study of Extra-Urban Sanctuaries in Minoan and Early Iron Age Crete. Aegaeum 15 (Liège: Université de Liège).

Westenholz, Joan G. 2002. 'Great Goddesses in Mesopotamia: The Female Aspect of Divinity', Canadian Society for Mesopotamian Studies 37: 13-26.

Xenaki-Sakellariou, Agnes. 1964. CMS I: Die Minoischen und Mykenischen Siegel des Nationalmuseum in Athen (Berlin: Gebr. Mann Verlag).

Yasur-Landau, Assaf and Nurith Goshen. 2014. 'The Reformed Mountains: Political and Religious Landscapes in the Aegean and the Levant', in G. Touchais, R. Laffineur and F. Rougemont (eds.) Physis: L'Environnement Naturel et la Relation Homme-Milieu dans le Monde Égéen Protohistorique. Actes de la $14^{e}$ Rencontre égéenne internationale, Paris, Institut National d'Histoire de l'Art (INHA) 11-14 décembre 2012. Aegaeum 37 (Peeters: Leuven): 159-163. 
Zedeño, María N. 2008. 'The Archaeology of Territory and Territoriality', in B. David and J. Thomas (eds.) Handbook of Landscape Archaeology (Walnut Creek: Left Coast Press): 210217. 


\section{University Library}

\section{- M M N E R VA A gateway to Melbourne's research publications}

Minerva Access is the Institutional Repository of The University of Melbourne

Author/s:

Tully, CJ;Crooks, S

Title:

Power Ranges: Identity and Terrain in Minoan Crete

Date:

2019-09-04

Citation:

Tully, C. J. \& Crooks, S. (2019). Power Ranges: Identity and Terrain in Minoan Crete. Journal for the Study of Religion, Nature and Culture, 13 (2), pp.130-156. https://doi.org/10.1558/ jsrnc.36629.

Persistent Link:

http://hdl.handle.net/11343/252797 